\title{
Quantitative Estimation of Urinary Sediment, with Special Regard to Sources of Error
}

\author{
H. GADEHOLT,* M.D.
}

Brit. med. F., 1964, 1, 1547-1549

In 1959 Pears and Houghton observed that the pyrogenic agent "pyrexal" increased the urinary excretion of leucocytes in patients with chronic pyelonephritis. This observation has been used as a diagnostic test in pyelonephritis. Montgomerie and North (1963), however, found a wide spontaneous variation in the white-cell excretion in patients with chronic pyelonephritis and never encountered the steady rates of excretion noted by Pears and Houghton (1959). They thought that the test was not reliable enough to be of value in the diagnosis of chronic pyelonephritis. The test is based on exact counting of the cells in the urine, and knowledge of the errors involved in this procedure is therefore of great importance.

The present study was carried out in order to correct some of the errors connected with quantitative estimation of urinary sediment.

The number of erythrocytes and leucocytes in the urine may be determined in two ways: (1) by semiquantitative methods -that is, counting the cells per high- or low-power field; and (2) by quantitative methods-counting the cells per unit of volume or the number of cells excreted per unit of time.

\section{Semiquantitative Methods}

The usual methods of measuring urinary sediments by counts per high- or low-power field are very inaccurate. In a study of common practice in urinalysis at independent laboratories Cook (1955) found a greater variation with these methods than with any other procedure employed in urinalysis. Moreover, the authors of various well-known textbooks differ greatly in their evaluation of cell contents in normal urine (Free et al., 1956). For instance, the number of red blood cells in normal urine ranges from none, through an occasional cell per lowpower field, to as many as 4 to 10 per high-power field, and the opinions of those authors regarding the number of cells that has clinical significance range from "any number at all" to " large numbers." This discrepancy is probably due to variables and errors in the technique, such as variations of the volume of urine in which the cells are excreted, the duration of the collecting period, the specific gravity of the urine, the $p \mathrm{H}$, the volume of urine centrifuged, the intensity of centrifugation, the volume of urine in the centrifuge tube in which the cells are resuspended, the method of transferring the sediment from the centrifuge tube to the slide, variable magnification, the thickness of the film beneath the coverslip, etc. This last variable is of especial interest because of the difficulties associated with its rapid estimation.

\section{Thickness of Film Beneath the Coverslip}

The thickness of this film depends within certain limits upon the amount of sediment transferred from the centrifuge tube. In routine laboratory work the transfer is performed by means of an ungraduated pipette or by simply pouring the sediment * From the University Clinic of Bergen, School of Medicine, Medical
Department B, Bergen, Norway. on the slide. In order to elucidate the errors in these procedures the following trial was made.

Forty urines were centrifuged, the supernatant urine was discarded, and the sediment was resuspended by vigorous shaking of the urine left in the centrifuge tube. Twenty specimens were prepared by transferring a drop of the sediment suspensions to the slides by various ungraduated pipettes (Pasteur pipettes), and 20 by simply pouring a drop on the slides. The sediments were covered with 18 by $18-\mathrm{mm}$. coverslips. The slides and coverslips were weighed before and after application of the sediment suspension, the difference thus giving the weight of the drop. In three instances, when more than $40 \mathrm{mg}$. was put on the slide, the sediment was not completely covered by the coverslip. The highest amount of sediment completely covered was $38.7 \mathrm{mg}$. The results are shown in Table I. The area of the coverslips was 324 sq. mm. Assuming that the specific gravity of the sediment is approximately 1000, the thickness of the sediment suspensions may vary between 0.025 and $0.08 \mathrm{~mm}$. when transferred by the help of an ungraduated pipette and approximately between 0.01 and $0.1 \mathrm{~mm}$. when transferred by pouring. Consequently the number of particles counted may vary from $n$ to approximately $3 \mathrm{n}$ when an ungraduated pipette is used, but from $\mathrm{n}$ to $10 \mathrm{n}$ when the sediment is transferred by pouring. Obviously, these methods of sediment-counting are not satisfactory.

TABLE I.-Weight of Sediment Suspension Transferred from Centrifuge-

\begin{tabular}{|c|c|c|c|}
\hline \multirow{2}{*}{ Mode of Transfer } & \multicolumn{3}{|c|}{ Weight in mg. } \\
\hline & Range & Median & Mean \\
\hline $\begin{array}{ll}\text { Ungraduated pipette } \\
\text { Pouring }\end{array}$ & $\begin{array}{l}8-27 \\
3 \cdot 8-57 \cdot 4\end{array}$ & $\begin{array}{l}15 \cdot 6 \\
18 \cdot 0\end{array}$ & $\begin{array}{l}16 \cdot 2 \\
20 \cdot 7\end{array}$ \\
\hline
\end{tabular}

\section{Quantitative Methods}

The method of exact counting of cells in the urine as introduced by Addis (1925) has gained little acceptance in routine clinical work chiefly because it is time-consuming. It may, however, be of practical importance in distinguishing between a high normal count and a low-grade but pathological increase ; for instance, after healing of a glomerulonephritis or pyelonephritis, or in the diagnosis of latent renal disease (Rew and Butler, 1932 ; Lyttle, 1933 ; Boyle et al., 1937 ; Snoke, 1937, 1938 ; Hamburger et al., 1950; Richet, 1953; Milliez and Lagrue, 1955 ; Merker and Kerp, 1958 ; Winter, 1958). Augmentation of these cells is reported in conditions in which no other renal involvement-for example, during fever in rheumatoid arthritis (Goldring and Wyckoff, 1930), pneumonia (Goldring, 1931), pregnancy (Elden and Cooney, 1935), scarlet fever (Lyttle, 1933), vigorous exercise (Roberts, 1935)-as well as after different treatments (Harvald et al., 1960 ; Clausen and Harvald, 1961).

\section{Material and Method}

The material comprised 75 male patients without symptoms or signs of disease of the urinary tract at any time. None of 
them had fever. Urine was collected from 7 a.m. to 9 a.m. The urethral orifice was cleaned with benzalkonium chloride before voiding. The volume of urine passed in this period ranged from 30 to $420 \mathrm{ml}$. (average $112 \mathrm{ml}$.), the specific gravity from 1012 to 1030 (average 1021), and the $p \mathrm{H}$ from 5 to 7 (average 6.1).

After thoroughly shaking the urine erythrocytes and leucocytes were counted in a volume of $6.4 \mathrm{c} . \mathrm{mm}$. in a FuchsRosenthal counting chamber. Simultaneously $10 \mathrm{ml}$. of urine was transferred to each of three graduated centrifuge tubes and centrifuged for five minutes at 1,000, 2,500, and 3,500 r.p.m. respectively, in a centrifuge with a radius of $16 \mathrm{~cm}$. Then 9 $\mathrm{ml}$. of the supernatant was discarded. The sediment was resuspended in the last $1 \mathrm{ml}$. at the bottom of the centrifuge tube with the help of a Pasteur pipette. The cells, which in this way were expected to be concentrated 10 times, were counted in a Fuchs-Rosenthal counting-chamber.

\section{Results}

Quantitative estimation of the cells in normal freshly voided urine before and after centrifugation revealed that $52.9 \%$ of the erythrocytes and $50.4 \%$ of the leucocytes present in uncentrifuged urine were recovered after centrifugation at 2,500 r.p.m. (Table II). There was, however, a wide variation in the number of cells recovered, varying from 20 to $115 \%$. With higher $(3,500$ r.p.m.) and lower (1,000 r.p.m.) spinning rates the percentages of cells recovered were still smaller.

TABLE II.-Percentage of Erythrocytes and Leucocytes in Urine
Recovered After Spinning for Five Minutes

\begin{tabular}{c|c|c}
\multicolumn{2}{c}{ Recovered After Spinning for Five Minutes } \\
\hline Centrifugation (r.p.m.) & Erythrocytes & Leucocytes \\
\hline 1,000 & $43.6 \%$ & $40.1 \%$ \\
2,500 & $52.9 \%$ & $50.4 \%$ \\
3,500 & $48.2 \%$ & $39.9 \%$ \\
\hline
\end{tabular}

The number of cells per c.mm. of unsedimented urine is given in Table III. In the greater part of the specimens the erythrocytes number less than $2 / \mathrm{c} . \mathrm{mm}$. and the leucocytes under 5/c.mm.

TABLE III.-Cell Counts in 75 Specimens of Unsedimented Normal Urine

\begin{tabular}{ll|c|c|c|c|c|c|c}
\hline & & \multicolumn{8}{|c}{ No. of Cells per c.mm. } \\
\cline { 3 - 8 } & & $<1$ & $1-$ & $2-$ & $3-$ & $4-$ & $5-$ & $10-12$ \\
\hline $\begin{array}{l}\text { Erythrocytes } \\
\text { Leucocytes }\end{array}$ & $\ldots$ & 46 & 16 & 6 & 3 & 2 & 1 & 1 \\
\end{tabular}

The number of erythrocytes excreted per hour in normal unsedimented urine ranged from 0 to 150,000 , with an average of 51,300. Correspondingly, the leucocytes ranged from 26,300 tc 359,000 , with an average of 104,000 .

\section{Errors of the Method}

Collecting Period.-Houghton and Pears (1957) found that the hourly excretion of leucocytes in the urine showed insignificant diurnal fluctuations, whereas Montgomerie and North (1963) observed wide variations. A longer period of collection will, however, result in a greater disintegration of the cells.

Specific Gravity.-A specific gravity below 1012 will accelerate the autolysis of the erythrocytes, which at S.G. 1004 is almost total (Winter and Knauth, 1952).

pH.-Small amounts of blood were suspended in phosphate buffers with $p \mathrm{H}$ ranging from 5 to 8 . With an electronic cellcounter (celloscope Ljungberg) 10 specimens from each of 10 suspensions were counted at once and after two hours, the latter time being chosen because our countings of urinary sediments were terminated within two hours after voiding. The error in counting was usually below $4 \%$ and did not exceed $10 \%$. Practically all the erythrocytes were recovered, but there was a slight decrease in the percentage at lower $p H$ (Table IV).

TABLE IV.-Percentage of Erythrocytes Recovered After Two Hours at Various $\mathrm{pH}$

\begin{tabular}{|c|c|c|c|c|c|c|c|c|}
\hline$\underset{\text { Erythrocytes recovered }}{\text { pH }}$ & $\because$ & $\begin{array}{r}5 \cdot 0 \\
89.7\end{array}$ & $\begin{array}{r}5 \cdot 5 \\
93 \cdot 2\end{array}$ & $\begin{array}{r}6.0 \\
96.9\end{array}$ & $\begin{array}{r}6.5 \\
99 \cdot 3\end{array}$ & $\begin{array}{r}7.0 \\
98.8\end{array}$ & $\begin{array}{r}7 \cdot 5 \\
97 \cdot 4\end{array}$ & $\begin{array}{r}8 \cdot 0 \\
97 \cdot 5\end{array}$ \\
\hline
\end{tabular}

\section{Centrifugation}

The object of centrifugation is to secure a total sedimentation of the contents. The centrifugal force is proportional to the weight of the particle and the square of the speed, and inversely proportional to the radius. Reznikoff (1923) found that the specific gravity of red blood cells washed free from plasma with $0.5 \%$ Ringer's solution varied from 1061 to 1073 , but with $1.3 \%$ Ringer's solution the range was 1104 to 1113 . The cells excreted in the urine have on their way from the renal capillaries been submitted to great variations in their environment with regard to osmolarity, electrolytes, $\mathrm{pH}$, etc. Some of the cells must be supposed to be destroyed by haemolysis and others more or less injured. Swelling of the cells will give a lower specific gravity and the centrifugation will be less effective. The lower specific gravity of the leucocytes may explain why a greater number of erythrocytes than leucocytes are recovered after centrifugation (Table II).

The radius has received little attention from authors, while the number of revolutions has often been discussed. Addis (1925) recommended a rate of 1,750 r.p.m. for five minutes, which he thought would give a total sedimentation. Næraa (1934) recommended a rate of 1,500 r.p.m., because a greater rate will pack the cells together and make it impossible to obtain an even suspension; whereas Kerp et al. (1956) recommended 2,800 r.p.m. (radius $10 \mathrm{~cm}$.), because at this rate only few cells were supposed to be left above the sediment. In our series small amounts of cells were recovered above the sediment even after centrifugation at 3,500 r.p.m.

The effect of centrifugation has been studied on suspensions of erythrocytes in physiological saline or cell-free (centrifuged or filtered) urine. Stone and Burke (1934) and Cook et al. (1956) were able to recover 50 to $80 \%$ of the erythrocytes after centrifugation ; Berg and Hovig (1959) recovered 60 to $90 \%$.

In order to test the accuracy of our method, known amounts of red blood cells were suspended in $10 \mathrm{ml}$. of Eagle's buffer and treated in the same way as the urine. In 100 specimens from 56 to $104 \%$ of the erythrocytes were recovered. The specimens were counted in duplicate after centrifugation for five minutes in two types of centrifuge tubes, with rounded and pointed bottoms respectively. An average of $79.7 \%$ and $74.4 \%$ of the erythrocytes were recovered from the two types of centrifuge tubes at a spinning rate of 2,500 r.p.m. Trial with siliconized and unsiliconized tubes gave no conclusive differences.

In cases of pyuria Hottinger (1893), after centrifugation and resuspension, recovered from 22 to $83 \%$ of the leucocytes present before centrifugation. Stone and Burke (1934) thought that $50 \%$ of the cells were recoverable, and Winter and Knauth (1957) found that one-third of the erythrocytes were not deposited. These findings are in conformity with the results in the present investigation (Table II). The loss of cells may thus be considerable and in the single specimen impossible to predict.

\section{Counting}

Only well-defined erythrocytes and leucocytes were counted. Disrupted cells were not included. Counting of duplicate 
specimens from the same portion of urine differed by 10 to $30 \%$. Duplicate counts from the same specimen in a FuchsRosenthal counting-chamber did not differ by more than $10 \%$. The results are expressed as an average of the duplicate counts.

\section{Discussion}

The counting of centrifuged as well as uncentrifuged urine is subject to errors. The smaller the specimen counted the less the chance of a representative sample and the greater the error. In many of the previous reports the cells in 1, 2, or 3.2 c.mm. of sediment suspension have been counted ; in the present series the count was made in $6.4 \mathrm{c.mm}$. Otaguro (1960) found that more exact results, with smaller margins of error, were obtained in centrifuged urine. In the present investigation centrifugation caused a variable loss of cells which could not be predicted. Hepler and Scott (1935) emphasized that so many variable factors were introduced by centrifugation that it was of no value in a quantitative estimation of the urinary white-cell content.

A way of estimating the number of cells in urine is to make the count in a known volume. Stansfeld and Webb (1953) found that in unsedimented urine $98 \%$ of the specimens from boys contained 10 or fewer cells per c.mm. These findings agree closely with our results from normal adult males (Table III). Rupp (1959) and de Almeida (1961) found that normal subjects never exhibit more than 10 leucocytes per c.mm. of urine. Such a way of expressing the number of cells is, however, less satisfactory, as the total volume of urine is not mentioned.

The counting of cells excreted in a definite period of time gives more exact results. The findings of various authors are summarized in Table V. For purposes of comparison their results, whether given as excretion per 12 hours or per minute, are here expressed as the number excreted per hour. As is shown, the values in the present investigation are higher than

TABLE V.-Unnary Excretion of Erythrocytes and Leucocytes

\begin{tabular}{|c|c|c|c|c|c|c|}
\hline \multirow[b]{2}{*}{ Authors } & \multicolumn{3}{|c|}{ Erythrocytes/Hour } & \multicolumn{3}{|c|}{ Leucocytes/Hour } \\
\hline & $\begin{array}{l}\text { Upper } \\
\text { Limit }\end{array}$ & $\begin{array}{l}\text { Lower } \\
\text { Limit }\end{array}$ & $\begin{array}{l}\text { Aver- } \\
\text { age }\end{array}$ & $\begin{array}{l}\text { Upper } \\
\text { Limit }\end{array}$ & $\begin{array}{l}\text { Lower } \\
\text { Limit }\end{array}$ & $\begin{array}{l}\text { Aver- } \\
\text { age }\end{array}$ \\
\hline 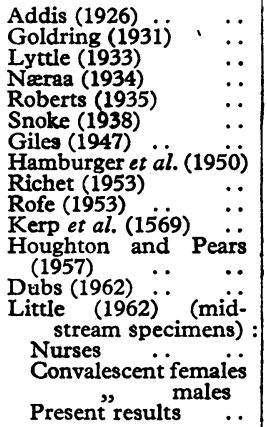 & $\begin{array}{r}35,417 \\
127,500 \\
10,750 \\
91,667 \\
3,540 \\
66,666 \\
6,000 \\
60,000 \\
13,000 \\
76,800\end{array}$ & $\begin{array}{r}0 \\
0 \\
0 \\
0 \\
2,420 \\
0\end{array}$ & $\begin{array}{r}5,479 \\
13,658 \\
1,265 \\
10,833 \\
2,980 \\
6,800\end{array}$ & $\begin{array}{r}152,917 \\
283,333 \\
325,167 \\
333,333 \\
23,580 \\
59,500 \\
30,000 \\
206,600 \\
96,600 \\
196,000 \\
250,000 \\
\\
109,000 \\
574,000 \\
220,000 \\
359,000\end{array}$ & $\begin{array}{r}28,200 \\
22,200 \\
18,000 \\
0 \\
\\
0 \\
0 \\
0 \\
26,300\end{array}$ & $\begin{array}{r}59,400 \\
87,700 \\
71,666 \\
\\
24,930 \\
95,000 \\
46,000 \\
104,000\end{array}$ \\
\hline
\end{tabular}

those previously reported. The reason for this may be the use of unsedimented urine ; besides, the period of collection was shorter than that commonly used, with less deterioration of the cells.

\section{Summary}

In semiquantitative counting of urinary sediment many variables are involved. The errors in transferring the sediment suspension from the centrifuge tube to the slide are recorded. The number of cells in the microscopic field varies from $\mathrm{n}$ to $10 \mathrm{n}$ when the sediment is transferred by pouring and from $\mathrm{n}$ to $3 \mathrm{n}$ when an ungraduated pipette is used.

The quantitative estimation of the urinary excretion of erythrocytes and leucocytes was carried out in 75 males without disease of the urinary tract. An average of 51,300 erythrocytes and 104,000 leucocytes were excreted per hour. These numbers are higher than those previously reported, possibly because the examination was carried out on uncentrifuged urine. The present investigation has shown that centrifugation causes an unpredictable loss of cells.

\section{REFERENCES}

Addis, T. (1925). 7. Amer. med. Ass., 85, 163.

(1926). F. clin. Invest., 2, 409.

de Almeida, S. (1961). Rev. Hosp. Clín. S. Paulo, 16, 163.

Berg, K. J., and Hovig, T. (1959). Scand. f. clin. Lab. Invest., 11, 217.

Boyle, H. H., Aldrich, C. A., Frank, A., and Borowsky, S. (1937). $\mathcal{F}$. Amer. med. Ass., 108, 1496.

Clausen, E., and Harvald, B. (1961). Acta med. scand., 170, 469.

Cook, M. H. (1955). Amer. f. med. Technol., 21, 232.

Free, H. M., and Free, A. H. (1956). Ibid., 22, 218.

Dubs, B. (1962). Praxis, 51, 258.

Elden, C. A., and Cooney, J. W. (1935). F. clin. Invest., 14, 889.

Free, H. M., Free, A. H., and Giordano, A. S. (1956). 7. Urol., 75, 743.

Giles, M. D. (1947). Arch. Dis. Childh., 22, 232.

Goldring, W. (1931). F. clin. Invest., 10, 355.

and Wyckoff, J. (1930). Ibid., 8, 569.

Hamburger, J., Mathé, G., and de Verbizier, J. (1950). Ann. Biol. clin., 8, 627 .

Harvald, B., Valdorf-Hansen, F., and Nielsen, A. (1960). Lancet, 1, 303.

Hepler, A. B., and Scott, R. T.'(1935). F. Amer. med. Ass., 165, 499.

Hottinger, R.' (1893). Zbl. med. Wiss., 3i, 257.

Houghton, B. J., and Pears, M. A. (1957). Brit. med. F., 1, 622

Kerp, L., Merker, H., and Frey, J. (1956). Klin. Wschr., 34, 1147.

Little, P.' J. (1962). Lancet, 1, 1149.

Lyttle, J. D. (1933). ₹. clin. Invjest., 12, 87, 95.

Merker, H., and Kerp, L. (1958). Arztl. Lab., 4, 101.

Milliez, P., and Lagrue, G. (1955). Gaz. méd. Fr., 62, 657.

Montgomerie, J. Z., and North, J. D. K. (1963). Lancet, 1, 690.

Næraa, A. (1934). Hospitalstidende, 77, 969, 1445.

Otaguro, K. (1960). Urol. int. (Basel), 10, 340.

Pears, M. A., and Houghton, B. J. (1959). Lancet, 2, 1167.

Rew, W. B., and Butler, A. M. (1932). f. Pediat., 1, 216.

Reznikoff, P. (1923). F. exp. Med., 38, 441 .

Richet, G. (1953). F. Urol. méd. chir., 59, 295.

Roberts, A. M. (1935). F. clin. Invest., 14, 31.

Rofe, P. (1955). F. clin. Path., 8, 25.

Rupp, W. (1959). Ärztl. Wschr., 14, 132.

Snoke, A. W. (1937). Amer. F. Dis. Child., 53, 673.

- (1938). f. Pediat., 12, 473.

Stansfeld, J. M., and Webb, J. K. G. (1953). Arch. Dis. Childh., 28, 386

Stone, W. J., and Burke, G. T. (1934). F. Amer. med. Ass., 102, 1549.

Winter, K. A. (1958). Arztl. Lab., 4, 112 .

Winter, K. A. (1958). Arztl. Lab., 4, 112.

- and Knauth, Th. (1952). Z. inn. Med. 